\title{
Growth and Differentiation Factor-5 Contributes to the Structural and Functional Maintenance of the Intervertebral Disc
}

\author{
Chencheng Feng Huan Liu Yang Yang Bo Huang Yue Zhou
}

Department of Orthopedics, Xinqiao Hospital, Third Military Medical University, Chongqing,

People's Republic of China

\section{Key Words}

Growth and differentiation factor-5 - Intervertebral disc degeneration • Biological theraphy

- Tissue regeneration

\begin{abstract}
Intervertebral disc degeneration (IDD) is a widely recognized contributor to low back pain (LBP). The Prevention or reversal of IDD is a potential treatment for LBP. Unfortunately, current treatments for IDD are aimed at relieving symptoms rather than regenerating disc structure or function. Recently, the injection of growth factors and mesenchymal stem cell (MSC) transplantation have been shown to be promising biological therapies for IDD. Growth factors stimulate the proliferation of and matrix synthesis by intervertebral disc (IVD) cells, leading to the regeneration of degenerative discs. Growth factors, hypoxia and co-culture with nucleus pulposus (NP) cells induce MSCs to differentiate toward an NP-like phenotype, which can increase the number of functional cells in the IVD or enhance the function of endogenous disc cells to facilitate IVD regeneration. Therefore, the emerging roles of growth factors in IVD regeneration have piqued the interest of researchers. Growth factors including transforming growth factor- $\beta$ (TGF- $\beta$ ), fibroblast growth factor (FGF), insulin-like growth factor-1 (IGF-1) and growth and differentiation factor-5 (GDF-5), among others, have been demonstrated to enhance anabolism in IVD cells and to induce NP-like differentiation of MSCs. However, the injection of TGF, IGF and FGF into human IVDs may induce unwanted blood vessel ingrowth, which accelerates the process of IDD, the injection of GDF-5 may not have the same effect. This finding suggests that GDF-5 is a preferable growth factor for use in IDD treatment compared with TGF, IGF and FGF. The GDF-5 gene is one of the few growth factor genes that have been

Yue Zhou

Department of Orthopedics, Xinqiao Hospital, Third Military Medical University, Xinqiao Main Street 183, 400037 Chongqing, Shapingba District (People's Republic of China)

Tel. +86-02368774328, Fax +86-02368774328, E-Mail happyzhou@vip.163.com
\end{abstract}

KARGER 125 
found to be associated with IDD thus far; moreover, the GDF-5 gene defects lead to collagen and proteoglycan abnormalities in discs in mice, suggesting that GDF-5 contributes to the structural and functional maintenance of the IVD. This review is focused on the functions of GDF-5 in the IVD and on the association between GDF-5 and a genetic predisposition to IDD. The effects of GDF-5 on IVD regeneration and on MSC differentiation are also discussed. GDF5 plays a crucial role in the pathogenesis of IDD and is a promising therapeutic agent for IDD. Additionally, stem cell transplantation has been shown to be a promising biological therapy for IDD.

Copyright (C) 2015 S. Karger AG, Basel

\section{Introduction}

LBP is one of the most prevalent musculoskeletal diseases worldwide. Approximately $70 \%$ of adults suffer from LBP at one time in their lives, and many of them are disabled [1]. The socio-economic burdens related to LBP are massive. In the USA, approximately $25 \%$ of the population suffers from LBP and neck pain, and the associated costs reached approximately $\$ 85$ billion in 2008 [2]. Thus, LBP represents a significant threat to human health and is a major drain on limited medical resources [2-4].

Intervertebral disc degeneration (IDD) is widely accepted as a main cause of LBP $[5,6]$. IDD is defined as an aberrant cell-mediated response to progressive structural failure [7] and is characterized by a loss of water signal intensity detected by T2-weighted MRI in the nucleus pulposus (NP) combined with a loss of disc height, annular tears, inflammation and bulging or herniation of the NP (Fig. 1B). Prevention or reversal of IDD is a potential treatment for LBP. However, current treatment methods for IDD, including surgery and conservative measures such as medications, steroid injection, and physical therapy, are aimed at treating symptoms rather than at regenerating disc structure or function.

Because IVD tissue homeostasis is maintained by a balance between anabolism and catabolism of disc cells, one of the potential therapeutic strategies to regenerate a degenerative disc is to up-regulate the anabolism and to down-regulate the catabolism induced by cytokines in the IVD [8]. Guided by this strategy, two advanced biological therapies are being widely investigated: injection of anabolic growth factors into degenerative IVDs [9, 10] and mesenchymal stem cell (MSC) transplantation [11, 12] (Fig. 2). Growth factors shift the metabolic status of IVD cells from the catabolic state to the anabolic state to regenerate degenerative discs [10]. Various growth factors have been demonstrated to stimulate the proliferation of and matrix synthesis by IVD cells in vitro, including transforming growth factor- $\beta$ (TGF- $\beta$ ), epidermal growth factor (EGF) $[13,14]$, insulin-like growth factor-1 (IGF1) [15], growth and differentiation factor-5 (GDF-5) [16, 17], osteogenic protein-1 (OP-1) $[18,19]$ and bone morphogenetic protein-2 (BMP-2) [20, 21]. Furthermore, in vivo, OP-1 and GDF-5 have been determined to induce the restoration of disc height and to increase the proteoglycan (PG) content in NP [22-24]. The results of these studies suggest the feasibility of including growth factor injections in biological therapies for IDD. MSC transplantation is also known as MSC-based therapy. The differentiation of MSCs toward an NP-like phenotype has been shown to be induced by growth factors, co-culture with disc cells, and hypoxia [2527]. TGF- $\beta$ [25], IGF-1, fibroblast growth factor- 2 (FGF-2), platelet-derived growth factor-BB $[28]$ and GDF-5 $[29,30]$ possessed the ability to induce NP-like differentiation of MSCs. The gene expression profiles of these induced MSCs resembled those of native IVD tissue more closely than those of joint cartilage [31]. Thus, these NP-like cells might be transplanted into degenerative IVDs to increase the number of functional cells in IVDs or to enhance the function of endogenous disc cells to assist IVD regeneration [12, 32].

As mentioned above, growth factors are necessary and essential in the two advanced biological therapies for IDD. To date, growth factors that have been widely investigated include TGF, IGF, BMP and FGF. Among these, GDF-5, a member of the BMP family, piqued our interest. Receptors for TGF, IGF and FGF (TGFRII, IGFRI and FGFR3, respectively) were 


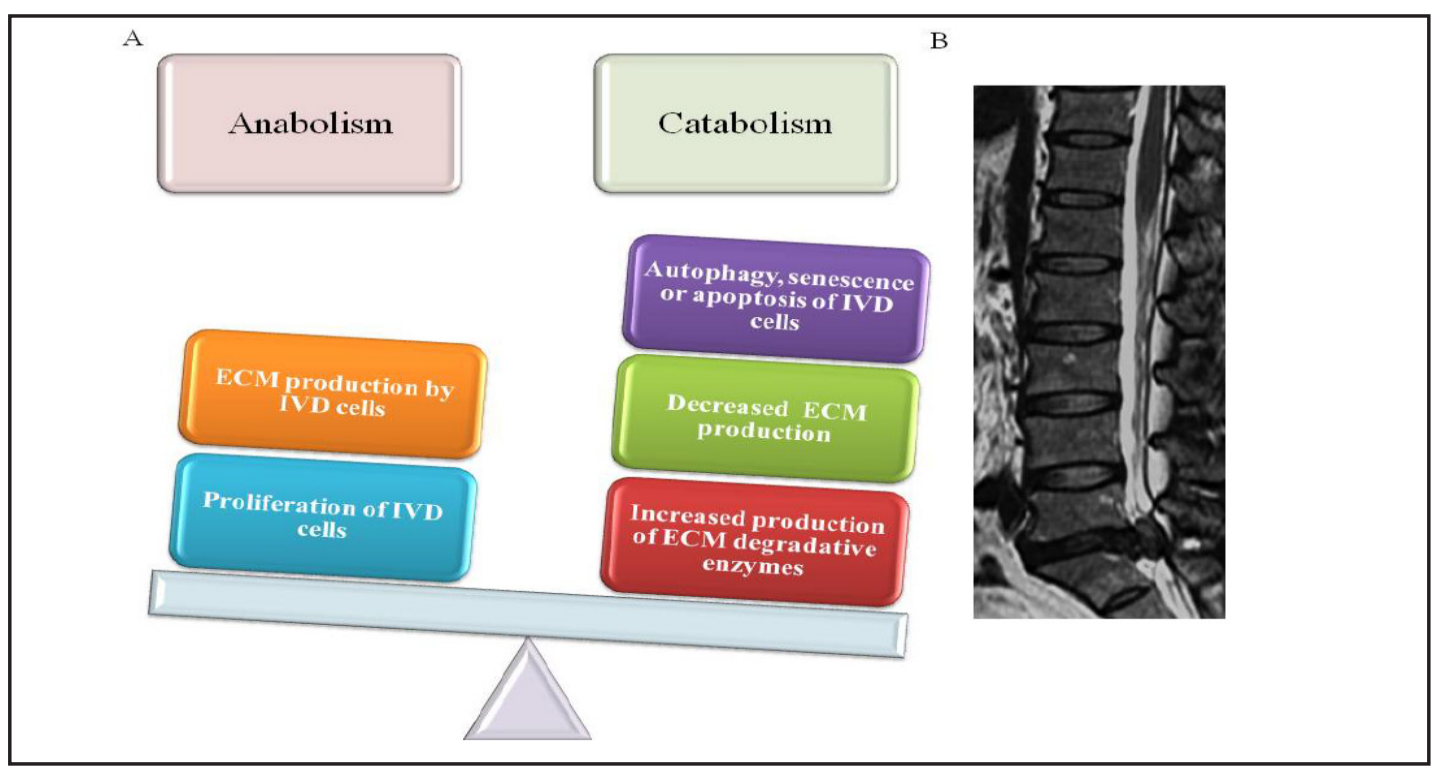

Fig. 1. The molecular basis of IDD (A) and the T2 MRI image of IDD (B). A. The imbalance between anabolism and catabolism in IVD cells causes structural deficits of IVD and accelerates the process of IDD. The autophagy along with senescence or apoptosis of IVD cells as well as decreased ECM production and increased production of ECM degradative enzymes enhance catabolism in IVD cells. B. The T2-weighted MRI image showing the loss of water signal in the NP of L5-S1 along with loss of disc height as well as bulging or herniation of the NP.

Fig. 2. Two advanced biological therapies for IDD. The widely investigated therapeutic strategy for IDD is to up-regulate anabolism and down-regulate catabolism in IVD cells. Under this strategy, growth factor injection and MSC transplantation are proposed as the potential biological therapies for IDD. Grow factors shift the metabolic status of IVD cells to regenerate degenerative discs. MSCs differentiate toward an NP-like phenotype, which aids in the disc regeneration.

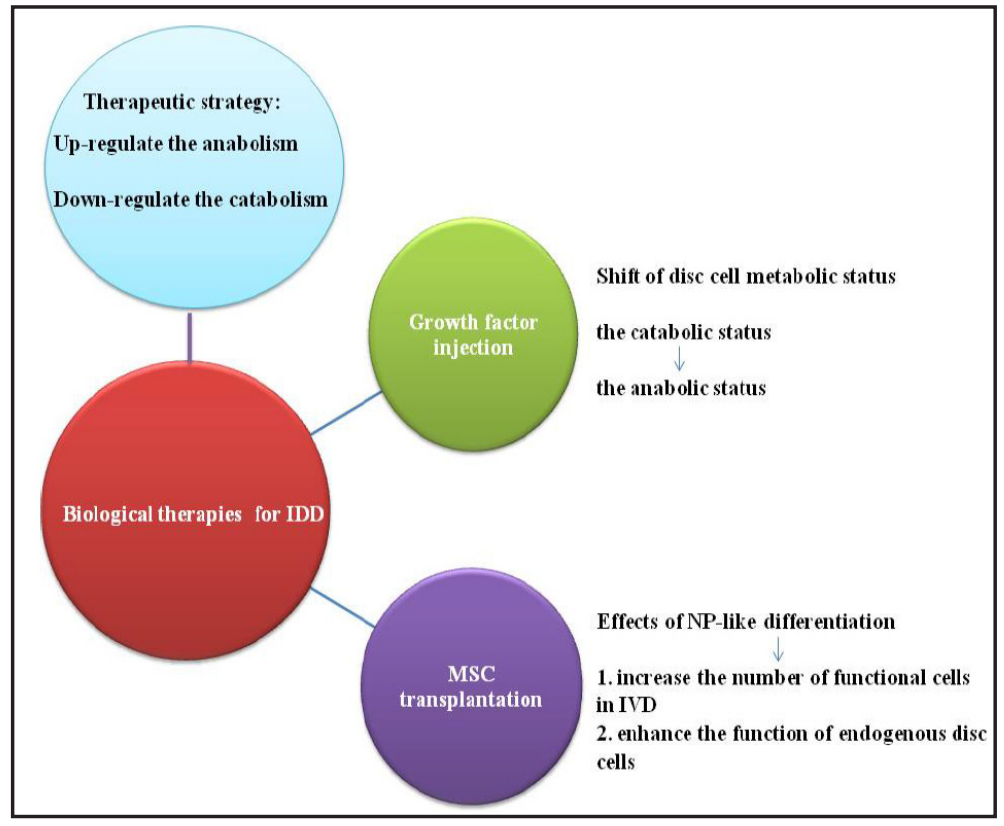

demonstrated to be expressed on the ingrowing blood vessels in human degenerative IVDs. The angiogenic potential of TGF- $\beta$, FGF and IGF suggests that the injection of these factors into the human IVD may induce blood vessel ingrowth to enhance the degree of IDD. However, BMP receptor II, a type of GDF-5 receptor, was not observed in the infiltrated blood vessels, suggesting that GDF-5 may not induce unwanted blood vessel ingrowth. GDF5 appears to be a preferable growth factor for use in biological therapies for IDD compared with TGF, IGF and FGF [33]. Moreover, the GDF-5 gene was shown to be a susceptibility gene for IDD [34,35]. Recently, various genes have been analyzed in association with the genetic

\section{KARGER}


Feng et al.: GDF-5 Contributes to Maintenance of IVD

predisposition to IDD. These genes included structural genes (aggrecan; collagen types I, IX, and XI; fibronectin, and others), catabolic genes (matrix metalloproteinase (MMP) 1, 2,3 , and others), anticatabolic genes (tissue inhibitor of metalloproteinase (TIMP)), and inflammatory genes (cyclooxygenase-2 (COX2), IL1- $\alpha$, IL1- $\beta$, and IL-6) [36]. Notably, The GDF-5 gene is one of the few growth factor genes that have been found to be associated with IDD thus far [34, 35]. The defects in the GDF-5 gene led to collagen and proteoglycan disc abnormalities in mice, suggesting the importance of GDF-5 in IVD matrix homeostasis [16]. The results noted above suggest the potential importance of GDF-5 beyond that of other growth factors. The functions of GDF- 5 warrant investigation to further elucidate IDD pathogenesis. Herein, we introduce the pathogenesis of IDD and describe the molecular structure of and the receptors for GDF-5 in brief. Then, we provide an introduction to the functions of GDF-5 in IVD. Additionally, current advances regarding the association between the GDF-5 gene and a genetic predisposition to IDD are summarized. Last, we focus our discussion on the potential applications of GDF-5 in biological therapies for IDD.

\section{The pathogenesis of IDD}

IDD is believed to be caused by aging, smoking, infection, excessive mechanical loading, decreased nutrient supplies and genetic predisposition [37-43]. These etiologic factors initiate the process of IDD mediated by the aberrant production of pro-inflammatory cytokines secreted by NP cells, annulus fibrosus (AF) cells, and infiltrated immune cells [4446]. Pro-inflammatory mediators, including TNF- $\alpha$, IL-1 $\alpha$, IL-1 $\beta$, IL-6, IL-17, and various chemokines [47-52], induce autophagy, senescence or apoptosis of IVD cells [37, 53-58]; decreased extracellular matrix (ECM) production $[59,60]$; and increased production of ECM degradative enzymes $[61,62]$. As a result, the balance between anabolism and catabolism is disrupted in IVD (Fig. 1A), causing structural deficits of the NP and the AF as well as disc herniation under excessive mechanical loading. Concurrently, blood vessels and nociceptive nerve fibers from the dorsal root ganglion (DRG) invade into the herniated disc tissues to cause LBP [63-65]. Notably, genetic polymorphisms in various genes have been investigated in association with IDD, including the vitamin D receptor [66, 67]; aggrecan [68, 69]; GDF5 [34, 35]; TIMP [66]; cartilage intermediate layer protein (CILP) [70, 71]; MMP 1, 2, and 3 [72-74]; and others. Each of these mutant genes encodes a protein that has a role in the pathophysiology of disc degeneration. Interestingly, although the GDF-5 gene is the one of the few growth factor genes that has been found to be associated with IDD thus far, the role of genetic polymorphisms in GDF-5 in disc degeneration remains unknown. Elucidating the functions of GDF-5 should benefit our understanding of IDD pathogenesis.

\section{GDF-5: a member of the BMP family}

GDF-5, also known as cartilage-derived morphogenetic protein-1 (CDMP-1), was identified as a new member of the TGF- $\beta$ superfamily in 1994 [75]. That same year, human GDF-5 was cloned by Chang et al. [76] and by Hotten et al. [77]. GDF-5 is synthesized as a large precursor protein containing an $\mathrm{N}$-terminal signal sequence, a prodomain with 358 amino acids and an active domain with 124 amino acids in the carboxyl terminus. The precursor protein then undergoes an endopeptidase cleavage at a characteristic R-X-X-R site to release a C-terminal mature peptide. This peptide includes 7 conserved cysteine residues that regulate disulfide-linked dimer formation at the C-terminus. X-ray crystallography was used to determine the 3D structure of recombinant human GDF-5. The results revealed that cysteine knots were characteristic 3D structures found within each subunit. A disulfide bridge was formed between the two subunits, allowing the formation of an active homodimer [78-80]. 
Feng et al.: GDF-5 Contributes to Maintenance of IVD

GDF-5 binds to the transmembrane serine/threonine kinase type I and II receptors to activate its signaling pathway [81, 82]. BMPR-1B (BMP receptor IB), BMPR-II, and activin receptor (ActR) type IIB have higher affinities for the GDF-5 ligand [83-85]. Upon GDF-5 binding, the receptors are phosphorylated to activate the downstream Smad pathway. The Smad proteins then translocate into the nucleus to regulate the transcription of various genes [86, 87].

\section{Functions of GDF-5 in IVD}

GDF-5 plays crucial roles in musculoskeletal development. During early limb development, GDF-5 expression is detected in precartilage condensations [75]. As the embryo develops, GDF-5 is expressed in the cartilaginous core of long bones, in articular surfaces and in osteoblast-like cells from the primary ossification centers of long bones [76], suggesting that GDF-5 is critical for the development of bone and joints. Additionally, GDF-5 has been demonstrated to play important roles in a variety of musculoskeletal physiological processes, such as endochondral ossification, the formation of ligaments and tendons and ligament maintenance and repair [88-94]. Considering the pleiotropic effects of GDF-5 in the musculoskeletal system, it is expected to play roles in IVD. In a loss-of-function study, GDF5 -deficient mice showed lumbar disc defects characterized by lower T2-weighted signal intensity in the NP accompanied by structural (histological) damage in the NP and AF [16]. However, the mRNA of GDF- 5 was localized to the annulus fibrosus rather than to NP tissues in mouse embryos. It was found that notochord cells formed normal NP tissues in GDF-5deficient mice [95]. Thus, the disc defects of GDF-5-deficient mice were likely caused by progressive postnatal degeneration of NP rather than by abnormal formation of the NP from the notochord during embryogenesis. This finding suggests that GDF-5 does not participate in the formation of the NP in embryonic mice; however, it plays a crucial role in postnatal IVD maintenance. Moreover, in the GDF-5-deficient mice, the expression of aggrecan and collagen type II in IVD cells was significantly down-regulated, and the PG content in discs was decreased. GDF-5 treatment up-regulated the expression of aggrecan and collagen type II in disc cells from GDF-5-deficient mice in a dose-dependent manner [16]. Notably, GDF-5 was shown to enhance the proliferation of bovine NP cells and AF cells in vitro. Concurrently, GDF-5 also significantly enhanced PG and collagen synthesis in both cell types [17]. Furthermore, GDF-5 was demonstrated to down-regulate MMP-3 gene expression in mouse disc cells, suggesting that GDF-5 suppresses ECM catabolism in IVD [96]. The results of these studies suggest that GDF-5 is effective in suppressing ECM degradation and in enhancing the proliferation and matrix anabolism of IVD cells (Fig. 3).

In humans, GDF-5 was shown to be expressed in both normal and degenerative IVDs, particularly in NP cells. However, the number of cells expressing GDF-5 was decreased in degenerative human IVDs. GDF-5 treatment up-regulated expression of aggrecan and collagen type II in NP cells isolated from degenerative IVDs and induced greater production of PG [97]. These findings indicate that GDF-5 is produced by human IVD cells and that it promotes ECM anabolism in IVD. Thus, GDF-5 aids in maintaining the structural integrity of the IVD. However, GDF-5 expression in IVD cells was shown to be suppressed by proinflammatory cytokines such as TNF- $\alpha$ and IL-1ß (Fig. 3) [98]. Therefore, it is possible that the suppression of GDF-5 expression down-regulates ECM anabolism in the IVD to accelerate the process of IDD.

\section{GDF-5 gene polymorphisms associated with IDD}

Mutations in GDF-5 have been shown to be associated with several skeletal disorders such as brachydactylies (BDs), multiple synostoses syndrome [99-102], Du Pan type chondrodysplasia (DPC), Grebe-type chondrodysplasia (GTC) [103-107], angel-shaped 


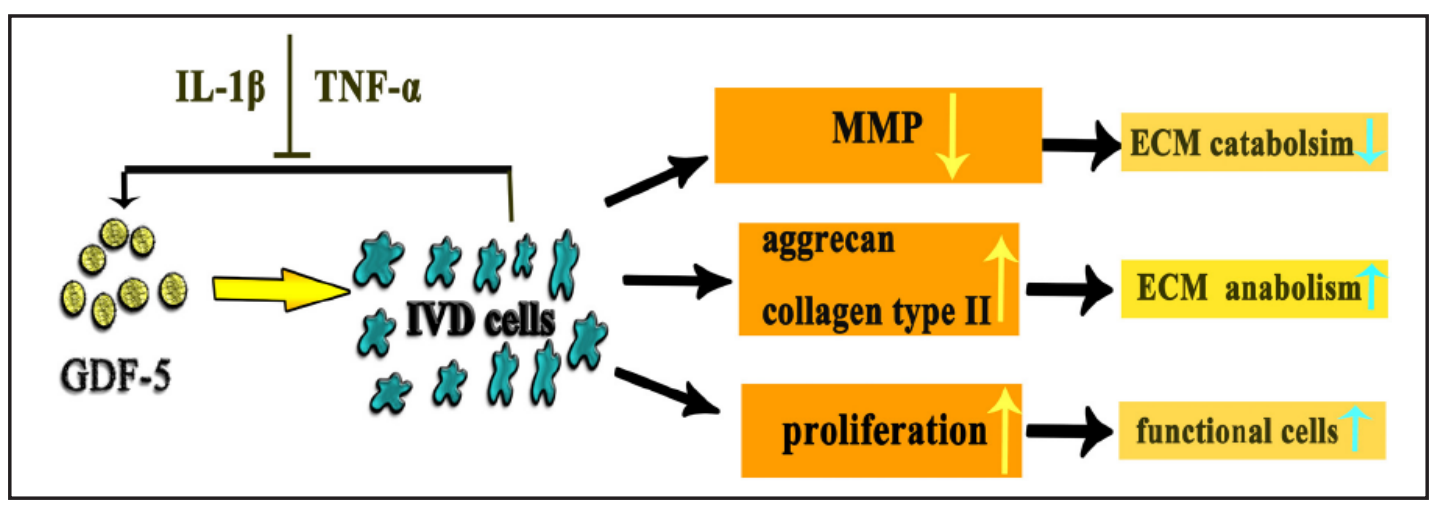

Fig. 3. Functions of GDF-5 in IVD. GDF- 5 is produced by IVD cells, which are suppressed by IL-1 $\beta$ and TNF- $\alpha$. It down-regulates the expression of MMP to inhibit the ECM catabolism, and up-regulates the expression of aggrecan and collagen type II to enhance the ECM anabolism. Additionally, GDF-5 also stimulates the proliferation of IVD cells, which increases the number of functional cells in IVD. The pleiotropic effects of GDF-5 contribute to the functional and structural maintenance of IVD.

phalangeal dysplasia (ASPED), proximal symphalangism, and congenital vertical talus [108110], which are consistent with the pleiotropic effects of GDF-5 on the musculoskeletal system. GDF-5 is also a susceptibility gene for osteoarthritis (OA), which is a polygenic degenerative skeletal disorder. The GDF5 single-nucleotide polymorphism (SNP) rs143383 has been demonstrated to be a susceptibility allele for OA [111-113]. The SNP rs143383, a T-to-C transition, is also associated with congenital hip dysplasia in Han Chinese and French Caucasian populations [114, 115]; it is located within the $5^{\prime}$ untranslated region (UTR) of the GDF-5 gene and within the GDF-5 promoter. The T-allele frequency of the gene was found to be elevated in patients with OA [111]. The expression of the OA-associated T allele was lower than that of the $C$ allele in synovial joint tissues from OA patients, suggesting an imbalance between the expression of the $\mathrm{C}$ and $\mathrm{T}$ alleles of this SNP $[116,117]$. This allelic expression imbalance (AEI) causes a joint-wide reduction in GDF-5 expression, which is assumed to trigger individual susceptibility to OA [116]. This hypothesis is supported by a study in mouse arthritis models. Mice with GDF-5 deficiency presented more severe osteoarthritic changes than wild type mice [118]. Recently, the transcription of the two alleles of this SNP was reported to be suppressed by the binding of the trans-activating factors Sp1, Sp3, P15, and DEAF1, leading to the AEI that underlies the OA susceptibility mediated by this SNP [119]. CpG methylation was demonstrated to regulate GDF-5 expression by modulating the binding of the SP1, SP3 and DEAF1 transcriptional repressors [120].

IDD is also one of the degenerative skeletal disorders that is influenced by both genetic and environmental factors [121]. Identification of susceptibility genes is crucial for elucidating the etiology and pathogenesis of IDD and for the development of new therapies for IDD. Approximately 20 genes have been investigated in association with IDD [36]. Interestingly, GDF5 rs143383 was demonstrated to be associated with IDD in northern European women and a Chinese military cohort. The T-allele frequency was also elevated in patients with IDD, suggesting that the GDF-5 gene is a susceptibility gene for IDD [34, 35]. The effect of rs143383 on GDF-5 allelic expression may be similar to the effect on OA. However, the AEI identified in OA tissues has not been investigated in degenerative disc tissues. No studies thus far have investigated whether the transcription of the two alleles of the SNP in IDD patients is also regulated by the trans-activating factors Sp1, Sp3, P15 and DEAF1 or by CpG methylation. Thus, further studies will be required to elucidate how the rs143383 SNP regulates GDF-5 allelic expression to mediate IDD susceptibility. Because IDD shares a common susceptibility allele with OA, this finding suggests that both diseases have a common molecular pathology that may involve a cellular growth and differentiation pathway, which might serve as a possible route to further understanding the pathogenesis of IDD. 
Feng et al.: GDF-5 Contributes to Maintenance of IVD

Table 1. The in vitro effects of GDF-5 on IVD cells from different species. IVD: intervertebral disc, AG: aggrecan, COL II: collagen Type II, DA: deoxyribonucleic acid, PG: proteoglycan, GAG: glycosaminoglycan, MMP: matrix metalloproteinase

\begin{tabular}{llll}
\hline Species & Study design & Effect & Reference \\
\hline GDF-5-deficient mouse & GDF-5 & Up-regulation of AG and COL II genes & Li et al [16] \\
& treatment & & \\
Bovine & GDF-5 & Increase in PG and DA contents & Chujo et al. [17] \\
& treatment & Enhanced PG and COL II synthesis & \\
Mouse & GDF-5 & Increase in GAG/DNA ratio & Cui et al. [96] \\
& treatment & Up-regulation of AG and COL II genes & \\
& & Down-regulation of MMP-3 gene & \\
Human & GDF-5 & Up-regulation of AG and COL II genes & Le Maitre et al. [97] \\
& treatment & Increase in the production of PG & \\
\hline
\end{tabular}

\section{In vivo studies of GDF-5 injection}

GDF-5 was shown to promote the proliferation of disc cells and to regulate ECM metabolism in disc cells in vitro (Table 1), suggesting a potential application of GDF-5 in IVD regeneration $[17,96]$. However, the regenerative effects of GDF- 5 on degenerative discs should be verified in vivo. A single injection of GDF-5 was administered to degenerative murine discs induced by static compression [24]. At 4 weeks after treatment, the disc height was significantly increased. An increase in isogenic groups of fibrochondrocytes within the inner AF and NP was observed. In response to exogenous GDF-5, the annulus fibrochondrocytes expanded into the degenerated, hypocellular NP. These cells expressed aggrecan and collagen type II genes, suggesting increased ECM synthesis within the NP [24]. These results suggest that GDF-5 is a mitogen for annulus fibrochondrocytes. GDF-5 promotes the expansion of and ECM synthesis by annulus fibrochondrocytes, which increases cellularity and the ECM content within the NP. As a result, the height and the biomechanical stability of the degenerative disc are restored. In a rabbit model of disc degeneration induced by annular puncture, a single injection of recombinant human GDF- 5 was also shown to restore disc height with improvement in both histologic and MRI findings. MRI of the NP of GDF-5-treated discs showed stronger T2 signal intensity, suggesting that the hydrophilic properties of the NP were maintained after GDF-5 injection. Moreover, in the discs injected with GDF-5, the number of chondrocytic cells in the NP and rounded chondrocytes in the AF increased significantly [17]. The results of these studies suggest that GDF-5 injection can retard or reverse IDD. According to functional studies of GDF-5 and in vivo studies of GDF-5 injection, GDF-5 may arrest or reverse the process of IDD through two principal pathways. First, it is possible that GDF-5 promotes the proliferation of and ECM synthesis by disc cells to enhance anabolic metabolism in IVD. Alternatively, it is possible that GDF-5 downregulates the expression of catabolic genes such as MMP in disc cells to suppress catabolic metabolism in IVD [96]. However, further details about these pathways are not currently available. Additional studies will be needed to elucidate the mechanism by which GDF-5 injection triggers IVD regeneration. Concomitantly, the effects of GDF-5 injection on human degenerative discs should be investigated in the future.

\section{Alternative approaches to GDF-5 administration}

GDF-5 injection has been shown to be an effective method of administering GDF-5 into degenerative IVD. However, the effects of a single injection of GDF-5 are not sustained over a 
Feng et al.: GDF-5 Contributes to Maintenance of IVD

long period. Multiple GDF-5 injections can cause an inflammatory reaction in the discs [24], which limits the clinical applications of GDF-5 in biological therapy for IDD. Thus, alternative approaches of GDF- 5 administration have been proposed that can ensure that the effects of GDF-5 are sustained. Delivery of the GDF-5 gene was demonstrated to be an alternative method [122]. The GDF-5 gene was transferred into IVD cells using adenovirus or plasmid vectors, and GDF-5 protein production in the transfected IVD cells was confirmed. Expressed GDF-5 protein was shown to be bioactive: it promoted the growth and proliferation of disc cells as well as ECM production by these cells [96, 122]. Furthermore, in a mouse disc degeneration model induced by annulus needle puncture, an adenoviral vector carrying the GDF5 gene was injected into lumbar discs to evaluate the effects of GDF-5 gene therapy for IDD. The results showed that the GDF-5 gene was successfully expressed. GDF- 5 induced significant restoration of T2-weighted MRI signals and disc height. Disc histology was also improved after GDF-5 gene therapy [123]. These findings indicate that delivery of the GDF-5 gene is an effective method for GDF-5 administration. The newly introduced GDF-5 gene will be expressed and will retard or reverse IDD, similar to GDF-5 injection. However, the effects of GDF-5 gene therapy on human discs have not been investigated thus far. Importantly, the safety of GDF-5 gene therapy has not been determined.

Another alternative approach to GDF-5 administration is the injection of poly (lacticco-glycolic acid) (PLGA) microspheres loaded with recombinant human GDF-5. These PLGA microspheres loaded with GDF-5 were injected into a rat caudal disc degeneration model induced by needle puncture, and the microspheres guaranteed sustained release of active GDF-5 protein for more than 42 days [124]. As a result, the disc height was restored significantly. Histological changes were improved by the PLGA microsphere treatment. Moreover, increases in glycosaminoglycan (GAG) and DNA content with an increase in collagen type II mRNA levels and an improvement in the differentiation index (the ratio of collagen type II to collagen type I) were also observed [124]. These findings suggest that the injection of GDF-5 loaded in PLGA microspheres is also an effective method of GDF-5 administration. Encapsulation of GDF-5 in PLGA microspheres guarantees that the therapeutic effects of GDF- 5 will be sustained over a long period and is a better method of GDF- 5 administration compared with GDF-5 injection. However, more studies will be needed to evaluate the effects of PLGA microspheres on human discs. To summarize, GDF- 5 should be administrated using a safe and convenient approach, which not only guarantees sustained therapeutic effects of GDF-5 but also guarantees safety.

\section{The effect of GDF-5 on the differentiation of MSCs toward an NP-like phenotype}

MSCs are promising graft cells for cell-based therapy of IDD [125, 126]. Transplanted MSCs are expected to differentiate into cells with an NP-like phenotype, and these NPlike cells could repair, maintain, and enhance the function of existing NP cells to arrest or reverse the process of IDD. However, the differentiation of MSCs depends on various biological microenvironmental factors. Growth factors including TGF- $\beta$, IGF-1, FGF- 2 and PDGF have been shown to induce the differentiation of MSCs into NP-like cells $[25,28]$. MSCs cultured under hypoxic conditions (2-3\% oxygen) showed enhanced NP-like and chondrogenic differentiation [25, 127, 128]. Furthermore, MSCs co-cultured with human NP cells showed increases in chondrogenic gene expression and ECM production $[26,129]$. However, the NP-like differentiation of MSCs in these studies was monitored using standard chondrogenic genes including aggrecan, collagen type II, and the transcription factor SOX9. Thus, the differences between NP-like differentiation and chondrogenic differentiation were not considered. Recently, several potential markers were identified that can be used to distinguish between chondrogenic and NP-like differentiation, including the aggrecan/ collagen type II ratio, cytokeratin 19 (KRT19), forkhead box F1 (FOXF1), and carbonic anhydrase 12 (CA12). The ratio of aggrecan to collagen is distinctly higher in the NP than in cartilage [130]. The expression of KRT19, FOXF1 and CA12 was shown to be up-regulated in 
Feng et al.: GDF-5 Contributes to Maintenance of IVD

the NP compared with articular chondrocytes and AF cells [70,131, 132]. It is hypothesized that these potential markers will be up-regulated during the process of NP-like differentiation when compared with chondrogenic differentiation [29, 30]. Interestingly, GDF-5 was shown to up-regulate the expression of aggrecan, collagen type II, and SOX-9 in MSCs $[133,134]$. Moreover, a combination of GDF-5 and hypoxia or co-culture with NP cells had a synergistic effect on NP-like differentiation of MSCs. Such interventions increased the aggrecan/collagen type II ratio and up-regulated the expression of KRT-19, FOXF1 and CA12 in MSCs [29, 30]. These findings suggest that GDF- 5 is suitable for inducing NP-like differentiation of MSCs, particularly when they are synergized by hypoxia and co-culture with NP cells.

In a recent study, the GDF-5 gene was transfected into human MSCs [135]. The transfected cells were grown in 3D cultures using alginate beads and were shown to express GDF-5 efficiently for up to 21 days. GDF-5 gene transfer along with 3D culture caused the up-regulation of SOX9, aggrecan and KRT19 expression in MSCs. Furthermore, the injection of GDF-5-transfected MSCs into an IVD organ culture model induced partial restoration of the GAG/DNA ratio. These results suggest that transfected MSCs could differentiate toward an NP-like phenotype and thus may serve as potential graft cells for MSC-based therapy for IDD [135]. However, another study showed that the carrier of MSCs might determine the fate of these cells without the need for GDF-5. For example, human MSCs cultured in a thermoreversible hyaluronan-based hydrogel, hyaluronan-poly ( $\mathrm{N}$-isopropylacrylamide) (HA-pNIPAM), under hypoxia differentiated toward an NP-like phenotype, regardless of whether GDF-5 was added [136]. Furthermore, in a bovine caudal disc organ culture model, human MSCs suspended in HA-pNIPAM without GDF-5 showed stronger NP-like differentiation than MSCs predifferentiated with GDF-5 in HA-pNIPAM [136]. These findings suggest that HA-pNIPAM induces the differentiation of MSCs toward an NP-like phenotype without the need for GDF-5. In conclusion, the differentiation of MSCs is influenced by various microenvironmental factors. The microenvironment in degenerative IVDs is highly complex, with many positive and negative factors influencing the fate of MSCs [12]. Thus, the manner in which MSCs are induced to differentiate toward an NP-like phenotype in harsh microenvironments should be explored in the future.

\section{Future perspectives}

GDF-5 has been demonstrated to suppress ECM degradation and to enhance the proliferation and matrix anabolism of IVD cells, suggesting that it contributes to the structural and functional maintenance of the IVD. However, GDF-5 has an extensive role in the musculoskeletal system, suggesting that it may have more functions in IVD beyond those cited. Thus, more studies are required to investigate the biological functions of GDF5 in IVD. Although GDF-5 gene polymorphisms were shown to be associated with IDD in northern European women and a Chinese military cohort [34, 35], these previous studies used small sample sizes and non-stringent significance levels. Therefore, this association should be further investigated in broader populations. Furthermore, the mechanism by which rs143383 regulates GDF-5 allelic expression to mediate IDD susceptibility is not well understood. Exploration of these issues will help to elucidate the pathogenesis of IDD and will contribute to the development of new therapeutic targets. GDF-5 injection was shown to restore disc height and histologic changes in animal models of IDD, suggesting the feasibility of applying GDF-5 for the prevention or reversal of IDD at an early stage. However, the therapeutic effects of GDF-5 may be overestimated due to the lack of "repair" cells in human IVD. Therefore, further studies will be required to investigate whether GDF-5 injection prevents IDD effectively. Additionally, to guarantee that the therapeutic effects of GDF-5 are sustained, more safe and convenient approaches to GDF-5 administration should be investigated. GDF-5 was confirmed to induce NP-like differentiation of MSCs, and MSCs with an NP-like phenotype are promising graft cells for use in MSC-based therapy for IDD. Thus, preclinical studies and clinical trials will be required in the future. In summary, the 
functions of GDF-5 in IVD and the association between GDF-5 gene polymorphisms and IDD should be explored extensively. Such knowledge will help to uncover the pathogenesis of IDD and will aid the development of feasible, effective biological therapies for IDD that are based on GDF-5.

\section{Abbreviations}

GDF-5 (growth and differentiation factor-5); IVD ((intervertebral disc); IDD (intervertebral disc degeneration); LBP (low back pain); MSC (mesenchymal stem cell); PG (proteoglycan); NP (nucleus pulposus); AF (annulus fibrosus); TGF (transforming growth factor); EGF (epidermal growth factor); IGF (insulin-like growth factor); OP (osteogenic protein); BMP (bone morphogenetic protein); FGF (fibroblast growth factor); MMP (matrix metalloproteinase); TIMP (tissue inhibitor of metalloproteinase); ECM (extracellular matrix); DRG (dorsal root ganglion); BMPR (BMP receptor); OA (osteoarthritis); SNP (singlenucleotide polymorphism); AEI (allelic expression imbalance); GAG (glycosaminoglycan); KRT19 (cytokeratin 19); FOXF1 (forkhead box F1); CA12 (carbonic anhydrase 12); PDGF (platelet derived growth factor).

\section{Disclosure Statement}

This study was supported by the National Natural Science Foundation of China (No. 81271982; No. 81472076; No.81401801).

\section{Acknowledgements}

Chencheng Feng and Huan Liu are co-first authors. They analyzed data and wrote this paper. They contributed equally to this work. Yang Yang collected data. Bo Huang revised this paper. Yue Zhou designed this study.

\section{References}

1 Andersson GB: Epidemiological features of chronic low-back pain. Lancet 1999;354:581-585.

2 Martin BI, Deyo RA, Mirza SK, Turner JA, Comstock BA, Hollingworth W, Sullivan SD: Expenditures and health status among adults with back and neck problems. JAMA 2008;299:656-664.

3 Maniadakis N, Gray A: The economic burden of back pain in the uk. Pain 2000;84:95-103.

-4 Stewart WF, Ricci JA, Chee E, Morganstein D, Lipton R: Lost productive time and cost due to common pain conditions in the us workforce. JAMA 2003;290:2443-2454.

-5 Luoma K, Riihimaki H, Luukkonen R, Raininko R, Viikari-Juntura E, Lamminen A: Low back pain in relation to lumbar disc degeneration. Spine (Phila Pa 1976) 2000;25:487-492.

6 Takatalo J, Karppinen J, Niinimaki J, Taimela S, Nayha S, Mutanen P, Sequeiros RB, Kyllonen E, Tervonen O: Does lumbar disc degeneration on magnetic resonance imaging associate with low back symptom severity in young finnish adults? Spine (Phila Pa 1976) 2011;36:2180-2189.

7 Adams MA, Roughley PJ: What is intervertebral disc degeneration, and what causes it? Spine (Phila Pa 1976) 2006;31:2151-2161.

8 Masuda K: Biological repair of the degenerated intervertebral disc by the injection of growth factors. Eur Spine J 2008;17:S441-451.

-9 Masuda K, An HS: Prevention of disc degeneration with growth factors. Eur Spine J 2006;15:S422-432.

10 Masuda K, Oegema TR Jr, An HS: Growth factors and treatment of intervertebral disc degeneration. Spine (Phila Pa 1976) 2004;29:2757-2769.

11 Leung VY, Chan D, Cheung KM: Regeneration of intervertebral disc by mesenchymal stem cells: Potentials, limitations, and future direction. Eur Spine J 2006;15:S406-413.

12 Huang YC, Leung VY, Lu WW, Luk KD: The effects of microenvironment in mesenchymal stem cell-based regeneration of intervertebral disc. Spine J 2013;13:352-362. 
13 Thompson JP, Oegema TR Jr, Bradford DS: Stimulation of mature canine intervertebral disc by growth factors. Spine (Phila Pa 1976) 1991;16:253-260.

14 Gruber HE, Fisher EC Jr, Desai B, Stasky AA, Hoelscher G, Hanley EN Jr: Human intervertebral disc cells from the annulus: Three-dimensional culture in agarose or alginate and responsiveness to tgf-beta1. Exp Cell Res 1997;235:13-21.

15 Osada R, Ohshima H, Ishihara H, Yudoh K, Sakai K, Matsui H, Tsuji H: Autocrine/paracrine mechanism of insulin-like growth factor-1 secretion, and the effect of insulin-like growth factor-1 on proteoglycan synthesis in bovine intervertebral discs. J Orthop Res 1996;14:690-699.

16 Li X, Leo BM, Beck G, Balian G, Anderson GD: Collagen and proteoglycan abnormalities in the gdf-5deficient mice and molecular changes when treating disk cells with recombinant growth factor. Spine (Phila Pa 1976) 2004;29:2229-2234.

17 Chujo T, An HS, Akeda K, Miyamoto K, Muehleman C, Attawia M, Andersson G, Masuda K: Effects of growth differentiation factor-5 on the intervertebral disc--in vitro bovine study and in vivo rabbit disc degeneration model study. Spine (Phila Pa 1976) 2006;31:2909-2917.

18 Masuda K, Takegami K, An H, Kumano F, Chiba K, Andersson GB, Schmid T, Thonar E: Recombinant osteogenic protein-1 upregulates extracellular matrix metabolism by rabbit annulus fibrosus and nucleus pulposus cells cultured in alginate beads. J Orthop Res 2003;21:922-930.

19 Imai Y, Miyamoto K, An HS, Thonar EJ, Andersson GB, Masuda K: Recombinant human osteogenic protein-1 upregulates proteoglycan metabolism of human anulus fibrosus and nucleus pulposus cells. Spine (Phila Pa 1976) 2007;32:1303-1309; discussion 1310.

20 Tim Yoon S, Su Kim K, Li J, Soo Park J, Akamaru T, Elmer WA, Hutton WC: The effect of bone morphogenetic protein-2 on rat intervertebral disc cells in vitro. Spine (Phila Pa 1976) 2003;28:1773-1780.

21 Gilbertson L, Ahn SH, Teng PN, Studer RK, Niyibizi C, Kang JD: The effects of recombinant human bone morphogenetic protein-2, recombinant human bone morphogenetic protein-12, and adenoviral bone morphogenetic protein-12 on matrix synthesis in human annulus fibrosis and nucleus pulposus cells. Spine J 2008;8:449-456.

22 An HS, Takegami K, Kamada H, Nguyen CM, Thonar EJ, Singh K, Andersson GB, Masuda K: Intradiscal administration of osteogenic protein-1 increases intervertebral disc height and proteoglycan content in the nucleus pulposus in normal adolescent rabbits. Spine (Phila Pa 1976) 2005;30:25-31; discussion 31-22.

-23 Masuda K, Imai Y, Okuma M, Muehleman C, Nakagawa K, Akeda K, Thonar E, Andersson G, An HS: Osteogenic protein-1 injection into a degenerated disc induces the restoration of disc height and structural changes in the rabbit anular puncture model. Spine (Phila Pa 1976) 2006;31:742-754.

24 Walsh AJ, Bradford DS, Lotz JC: In vivo growth factor treatment of degenerated intervertebral discs. Spine (Phila Pa 1976) 2004;29:156-163.

25 Risbud MV, Albert TJ, Guttapalli A, Vresilovic EJ, Hillibrand AS, Vaccaro AR, Shapiro IM: Differentiation of mesenchymal stem cells towards a nucleus pulposus-like phenotype in vitro: Implications for cell-based transplantation therapy. Spine (Phila Pa 1976) 2004;29:2627-2632.

-26 Richardson SM, Walker RV, Parker S, Rhodes NP, Hunt JA, Freemont AJ, Hoyland JA: Intervertebral disc cellmediated mesenchymal stem cell differentiation. Stem Cells 2006;24:707-716.

27 Yang SH, Wu CC, Shih TT, Sun YH, Lin FH: In vitro study on interaction between human nucleus pulposus cells and mesenchymal stem cells through paracrine stimulation. Spine (Phila Pa 1976) 2008;33:19511957.

-28 Ehlicke F, Freimark D, Heil B, Dorresteijn A, Czermak P: Intervertebral disc regeneration: Influence of growth factors on differentiation of human mesenchymal stem cells (hmsc). Int J Artif Organs 2010;33:244-252.

29 Gantenbein-Ritter B, Benneker LM, Alini M, Grad S: Differential response of human bone marrow stromal cells to either tgf-beta(1) or rhgdf-5. Eur Spine J 2011;20:962-971.

-30 Stoyanov JV, Gantenbein-Ritter B, Bertolo A, Aebli N, Baur M, Alini M, Grad S: Role of hypoxia and growth and differentiation factor-5 on differentiation of human mesenchymal stem cells towards intervertebral nucleus pulposus-like cells. Eur Cell Mater 2011;21:533-547.

-31 Steck E, Bertram H, Abel R, Chen B, Winter A, Richter W: Induction of intervertebral disc-like cells from adult mesenchymal stem cells. Stem Cells 2005;23:403-411.

-32 Yang F, Leung VY, Luk KD, Chan D, Cheung KM: Mesenchymal stem cells arrest intervertebral disc degeneration through chondrocytic differentiation and stimulation of endogenous cells. Mol Ther 2009;17:1959-1966. 
33 Le Maitre CL, Richardson SM, Baird P, Freemont AJ, Hoyland JA: Expression of receptors for putative anabolic growth factors in human intervertebral disc: Implications for repair and regeneration of the disc. J Pathol 2005;207:445-452.

34 Williams FM, Popham M, Hart DJ, de Schepper E, Bierma-Zeinstra S, Hofman A, Uitterlinden AG, Arden NK, Cooper C, Spector TD, Valdes AM, van Meurs J: Gdf5 single-nucleotide polymorphism rs143383 is associated with lumbar disc degeneration in northern european women. Arthritis Rheum 2011;63:708712.

35 Mu J, Ge W, Zuo X, Chen Y, Huang C: Analysis of association between il-1beta, casp-9, and gdf5 variants and low-back pain in chinese male soldier: Clinical article. J Neurosurg Spine 2013;19:243-247.

-36 Mayer JE, Iatridis JC, Chan D, Qureshi SA, Gottesman O, Hecht AC: Genetic polymorphisms associated with intervertebral disc degeneration. Spine J 2013;13:299-317.

37 Roberts S, Evans H, Trivedi J, Menage J: Histology and pathology of the human intervertebral disc. J Bone Joint Surg Am 2006;88 Suppl 2:10-14.

-38 Kanayama M, Togawa D, Takahashi C, Terai T, Hashimoto T: Cross-sectional magnetic resonance imaging study of lumbar disc degeneration in 200 healthy individuals. J Neurosurg Spine 2009;11:501-507.

39 Cheung KM, Karppinen J, Chan D, Ho DW, Song YQ Sham P, Cheah KS, Leong JC, Luk KD: Prevalence and pattern of lumbar magnetic resonance imaging changes in a population study of one thousand forty-three individuals. Spine (Phila Pa 1976) 2009;34:934-940.

40 Battie MC, Videman T, Kaprio J, Gibbons LE, Gill K, Manninen H, Saarela J, Peltonen L: The twin spine study: Contributions to a changing view of disc degeneration. Spine J 2009;9:47-59.

41 Adams MA, Freeman BJ, Morrison HP, Nelson IW, Dolan P: Mechanical initiation of intervertebral disc degeneration. Spine (Phila Pa 1976) 2000;25:1625-1636.

42 Wang D, Nasto LA, Roughley P, Leme AS, Houghton AM, Usas A, Sowa G, Lee J, Niedernhofer L, Shapiro S, Kang J, Vo N: Spine degeneration in a murine model of chronic human tobacco smokers. Osteoarthritis Cartilage 2012;20:896-905.

43 Stirling A, Worthington T, Rafiq M, Lambert PA, Elliott TS: Association between sciatica and propionibacterium acnes. Lancet 2001;357:2024-2025.

44 Yamamoto J, Maeno K, Takada T, Kakutani K, Yurube T, Zhang Z, Hirata H, Kurakawa T, Sakai D, Mochida J, Doita M, Kurosaka M, Nishida K: Fas ligand plays an important role for the production of pro-inflammatory cytokines in intervertebral disc nucleus pulposus cells. J Orthop Res 2013;31:608-615.

45 Rand N, Reichert F, Floman Y, Rotshenker S: Murine nucleus pulposus-derived cells secrete interleukins1-beta, -6, and -10 and granulocyte-macrophage colony-stimulating factor in cell culture. Spine (Phila Pa 1976) 1997;22:2598-2601; discussion 2602.

46 Kepler CK, Markova DZ, Hilibrand AS, Vaccaro AR, Risbud MV, Albert TJ, Anderson DG: Substance p stimulates production of inflammatory cytokines in human disc cells. Spine (Phila Pa 1976) 2013;38:E1291-1299.

47 Le Maitre CL, Freemont AJ, Hoyland JA: The role of interleukin-1 in the pathogenesis of human intervertebral disc degeneration. Arthritis Res Ther 2005;7:R732-745.

48 Le Maitre CL, Hoyland JA, Freemont AJ: Catabolic cytokine expression in degenerate and herniated human intervertebral discs: Il-1beta and tnfalpha expression profile. Arthritis Res Ther 2007;9:R77.

49 Seguin CA, Pilliar RM, Roughley PJ, Kandel RA: Tumor necrosis factor-alpha modulates matrix production and catabolism in nucleus pulposus tissue. Spine (Phila Pa 1976) 2005;30:1940-1948.

50 Shamji MF, Setton LA, Jarvis W, So S, Chen J, Jing L, Bullock R, Isaacs RE, Brown C, Richardson WJ: Proinflammatory cytokine expression profile in degenerated and herniated human intervertebral disc tissues. Arthritis Rheum 2010;62:1974-1982.

51 Cuellar JM, Borges PM, Cuellar VG, Yoo A, Scuderi GJ, Yeomans DC: Cytokine expression in the epidural space: A model of noncompressive disc herniation-induced inflammation. Spine (Phila Pa 1976) 2013;38:17-23.

52 Kepler CK, Markova DZ, Dibra F, Yadla S, Vaccaro AR, Risbud MV, Albert TJ, Anderson DG: Expression and relationship of proinflammatory chemokine rantes/ccl5 and cytokine il-1beta in painful human intervertebral discs. Spine (Phila Pa 1976) 2013;38:873-880.

53 Purmessur D, Walter BA, Roughley PJ, Laudier DM, Hecht AC, Iatridis J: A role for tnfalpha in intervertebral disc degeneration: A non-recoverable catabolic shift. Biochem Biophys Res Commun 2013;433:151-156.

54 Shen C, Yan J, Jiang LS, Dai LY: Autophagy in rat annulus fibrosus cells: Evidence and possible implications. Arthritis Res Ther 2011;13:R132. 
55 Roberts S, Evans EH, Kletsas D, Jaffray DC, Eisenstein SM: Senescence in human intervertebral discs. Eur Spine J 2006;15:S312-316.

56 Le Maitre CL, Freemont AJ, Hoyland JA: Accelerated cellular senescence in degenerate intervertebral discs: A possible role in the pathogenesis of intervertebral disc degeneration. Arthritis Res Ther 2007;9:R45.

57 Liebscher T, Haefeli M, Wuertz K, Nerlich AG, Boos N: Age-related variation in cell density of human lumbar intervertebral disc. Spine (Phila Pa 1976) 2011;36:153-159.

-58 Zhao CQ, Jiang LS, Dai LY: Programmed cell death in intervertebral disc degeneration. Apoptosis 2006;11:2079-2088.

59 Singh K, Masuda K, Thonar EJ, An HS, Cs-Szabo G: Age-related changes in the extracellular matrix of nucleus pulposus and anulus fibrosus of human intervertebral disc. Spine (Phila Pa 1976) 2009;34:10-16.

60 Cs-Szabo G, Ragasa-San Juan D, Turumella V, Masuda K, Thonar EJ, An HS: Changes in mrna and protein levels of proteoglycans of the anulus fibrosus and nucleus pulposus during intervertebral disc degeneration. Spine (Phila Pa 1976) 2002;27:2212-2219.

61 Crean JK, Roberts S, Jaffray DC, Eisenstein SM, Duance VC: Matrix metalloproteinases in the human intervertebral disc: Role in disc degeneration and scoliosis. Spine (Phila Pa 1976) 1997;22:2877-2884.

62 Pockert AJ, Richardson SM, Le Maitre CL, Lyon M, Deakin JA, Buttle DJ, Freemont AJ, Hoyland JA: Modified expression of the adamts enzymes and tissue inhibitor of metalloproteinases 3 during human intervertebral disc degeneration. Arthritis Rheum 2009;60:482-491.

63 Freemont AJ, Watkins A, Le Maitre C, Baird P, Jeziorska M, Knight MT, Ross ER, O'Brien JP, Hoyland JA: Nerve growth factor expression and innervation of the painful intervertebral disc. J Pathol 2002;197:286-292.

64 Melrose J, Roberts S, Smith S, Menage J, Ghosh P: Increased nerve and blood vessel ingrowth associated with proteoglycan depletion in an ovine anular lesion model of experimental disc degeneration. Spine (Phila Pa 1976) 2002;27:1278-1285.

65 Vernon-Roberts B, Moore RJ, Fraser RD: The natural history of age-related disc degeneration: The pathology and sequelae of tears. Spine (Phila Pa 1976) 2007;32:2797-2804.

66 Valdes AM, Hassett G, Hart DJ, Spector TD: Radiographic progression of lumbar spine disc degeneration is influenced by variation at inflammatory genes: A candidate snp association study in the chingford cohort. Spine (Phila Pa 1976) 2005;30:2445-2451.

67 Videman T, Gibbons LE, Battie MC, Maravilla K, Vanninen E, Leppavuori J, Kaprio J, Peltonen L: The relative roles of intragenic polymorphisms of the vitamin $\mathrm{d}$ receptor gene in lumbar spine degeneration and bone density. Spine (Phila Pa 1976) 2001;26:E7-E12.

68 Kawaguchi Y, Osada R, Kanamori M, Ishihara H, Ohmori K, Matsui H, Kimura T: Association between an aggrecan gene polymorphism and lumbar disc degeneration. Spine (Phila Pa 1976) 1999;24:2456-2460.

69 Kim NK, Shin DA, Han IB, Yoo EH, Kim SH, Chung SS: The association of aggrecan gene polymorphism with the risk of intervertebral disc degeneration. Acta Neurochir (Wien) 2011;153:129-133.

70 Virtanen IM, Song YQ, Cheung KM, Ala-Kokko L, Karppinen J, Ho DW, Luk KD, Yip SP, Leong JC, Cheah KS, Sham P, Chan D: Phenotypic and population differences in the association between cilp and lumbar disc disease. J Med Genet 2007;44:285-288.

71 Min SK, Nakazato K, Yamamoto Y, Gushiken K, Fujimoto H, Fujishiro H, Kobayakawa Y, Hiranuma K: Cartilage intermediate layer protein gene is associated with lumbar disc degeneration in male, but not female, collegiate athletes. Am J Sports Med 2010;38:2552-2557.

72 Song YQ Ho DW, Karppinen J, Kao PY, Fan BJ, Luk KD, Yip SP, Leong JC, Cheah KS, Sham P, Chan D, Cheung KM: Association between promoter -1607 polymorphism of mmp1 and lumbar disc disease in southern chinese. BMC Med Genet 2008;9:38.

73 Dong DM, Yao M, Liu B, Sun CY, Jiang YQ, Wang YS: Association between the -1306 c/t polymorphism of matrix metalloproteinase-2 gene and lumbar disc disease in chinese young adults. Eur Spine J 2007;16:1958-1961.

74 Takahashi M, Haro H, Wakabayashi Y, Kawa-uchi T, Komori H, Shinomiya K: The association of degeneration of the intervertebral disc with $5 \mathrm{a} / 6 \mathrm{a}$ polymorphism in the promoter of the human matrix metalloproteinase-3 gene. J Bone Joint Surg Br 2001;83:491-495.

75 Storm EE, Huynh TV, Copeland NG, Jenkins NA, Kingsley DM, Lee SJ: Limb alterations in brachypodism mice due to mutations in a new member of the tgf beta-superfamily. Nature 1994;368:639-643. 
76 Chang SC, Hoang B, Thomas JT, Vukicevic S, Luyten FP, Ryba NJ, Kozak CA, Reddi AH, Moos M Jr: Cartilage-derived morphogenetic proteins. New members of the transforming growth factor-beta superfamily predominantly expressed in long bones during human embryonic development. J Biol Chem 1994;269:28227-28234.

77 Hotten G, Neidhardt H, Jacobowsky B, Pohl J: Cloning and expression of recombinant human growth/ differentiation factor 5. Biochem Biophys Res Commun 1994;204:646-652.

-78 Schreuder H, Liesum A, Pohl J, Kruse M, Koyama M: Crystal structure of recombinant human growth and differentiation factor 5: Evidence for interaction of the type i and type ii receptor-binding sites. Biochem Biophys Res Commun 2005;329:1076-1086.

79 Mueller TD, Gottermeier M, Sebald W, Nickel J: Crystallization and preliminary x-ray diffraction analysis of human growth and differentiation factor 5 (gdf-5). Acta Crystallogr Sect F Struct Biol Cryst Commun 2005;61:134-136.

80 Trachsel C, Kampfer U, Bechtold R, Schaller J, Schurch S: Elucidation of the disulfide bridge pattern of the recombinant human growth and differentiation factor 5 dimer and the interchain cys/ala mutant monomer. Anal Biochem 2009;390:103-108.

81 David L, Feige JJ, Bailly S: Emerging role of bone morphogenetic proteins in angiogenesis. Cytokine Growth Factor Rev 2009;20:203-212.

82 Heldin CH, Miyazono K, ten Dijke P: Tgf-beta signalling from cell membrane to nucleus through smad proteins. Nature 1997;390:465-471.

83 Heinecke K, Seher A, Schmitz W, Mueller TD, Sebald W, Nickel J: Receptor oligomerization and beyond: A case study in bone morphogenetic proteins. BMC Biol 2009;7:59.

84 Nickel J, Kotzsch A, Sebald W, Mueller TD: A single residue of gdf-5 defines binding specificity to bmp receptor ib. J Mol Biol 2005;349:933-947.

85 Nishitoh H, Ichijo H, Kimura M, Matsumoto T, Makishima F, Yamaguchi A, Yamashita H, Enomoto S, Miyazono K: Identification of type i and type ii serine/threonine kinase receptors for growth/ differentiation factor-5. J Biol Chem 1996;271:21345-21352.

86 Hata A, Seoane J, Lagna G, Montalvo E, Hemmati-Brivanlou A, Massague J: Oaz uses distinct DNA- and protein-binding zinc fingers in separate bmp-smad and olf signaling pathways. Cell 2000;100:229-240.

-87 Massague J: How cells read tgf-beta signals. Nat Rev Mol Cell Biol 2000;1:169-178.

-88 Tsumaki N, Tanaka K, Arikawa-Hirasawa E, Nakase T, Kimura T, Thomas JT, Ochi T, Luyten FP, Yamada Y: Role of cdmp-1 in skeletal morphogenesis: Promotion of mesenchymal cell recruitment and chondrocyte differentiation. J Cell Biol 1999;144:161-173.

-89 Wolfman NM, Hattersley G, Cox K, Celeste AJ, Nelson R, Yamaji N, Dube JL, DiBlasio-Smith E, Nove J, Song JJ, Wozney JM, Rosen V: Ectopic induction of tendon and ligament in rats by growth and differentiation factors 5, 6, and 7, members of the tgf-beta gene family. J Clin Invest 1997;100:321-330.

$\$ 90$ Mikic B: Multiple effects of gdf-5 deficiency on skeletal tissues: Implications for therapeutic bioengineering. Ann Biomed Eng 2004;32:466-476.

91 Mikic B, Clark RT, Battaglia TC, Gaschen V, Hunziker EB: Altered hypertrophic chondrocyte kinetics in gdf-5 deficient murine tibial growth plates. J Orthop Res 2004;22:552-556.

-92 Chhabra A, Tsou D, Clark RT, Gaschen V, Hunziker EB, Mikic B: Gdf-5 deficiency in mice delays achilles tendon healing. J Orthop Res 2003;21:826-835.

93 Clark RT, Johnson TL, Schalet BJ, Davis L, Gaschen V, Hunziker EB, Oldberg A, Mikic B: Gdf-5 deficiency in mice leads to disruption of tail tendon form and function. Connect Tissue Res 2001;42:175-186.

$\$ 94$ Mikic B, Schalet BJ, Clark RT, Gaschen V, Hunziker EB: Gdf-5 deficiency in mice alters the ultrastructure, mechanical properties and composition of the achilles tendon. J Orthop Res 2001;19:365-371.

$\$ 95$ Maier JA, Harfe BD: Nuclei pulposi formation from the embryonic notochord occurs normally in gdf-5deficient mice. Spine (Phila Pa 1976) 2011;36:E1555-1561.

-96 Cui M, Wan Y, Anderson DG, Shen FH, Leo BM, Laurencin CT, Balian G, Li X: Mouse growth and differentiation factor-5 protein and DNA therapy potentiates intervertebral disc cell aggregation and chondrogenic gene expression. Spine J 2008;8:287-295.

$\$ 97$ Le Maitre CL, Freemont AJ, Hoyland JA: Expression of cartilage-derived morphogenetic protein in human intervertebral discs and its effect on matrix synthesis in degenerate human nucleus pulposus cells. Arthritis Res Ther 2009;11:R137. 
Feng et al.: GDF-5 Contributes to Maintenance of IVD

-98 Gruber HE, Hoelscher GL, Ingram JA, Bethea S, Hanley EN Jr: Growth and differentiation factor-5 (gdf-5) in the human intervertebral annulus cells and its modulation by il-1ss and tnf-alpha in vitro. Exp Mol Pathol 2014;96:225-229.

99 Byrnes AM, Racacho L, Nikkel SM, Xiao F, MacDonald H, Underhill TM, Bulman DE: Mutations in gdf5 presenting as semidominant brachydactyly a1. Hum Mutat 2010;31:1155-1162.

$>100$ Kjaer KW, Eiberg H, Hansen L, van der Hagen CB, Rosendahl K, Tommerup N, Mundlos S: A mutation in the receptor binding site of gdf5 causes mohr-wriedt brachydactyly type a2. J Med Genet 2006;43:225-231.

101 Polinkovsky A, Robin NH, Thomas JT, Irons M, Lynn A, Goodman FR, Reardon W, Kant SG, Brunner HG, van der Burgt I, Chitayat D, McGaughran J, Donnai D, Luyten FP, Warman ML: Mutations in cdmp1 cause autosomal dominant brachydactyly type c. Nat Genet 1997;17:18-19.

102 Dawson K, Seeman P, Sebald E, King L, Edwards M, Williams J, 3rd, Mundlos S, Krakow D: Gdf5 is a second locus for multiple-synostosis syndrome. Am J Hum Genet 2006;78:708-712.

103 Douzgou S, Lehmann K, Mingarelli R, Mundlos S, Dallapiccola B: Compound heterozygosity for gdf5 in du pan type chondrodysplasia. Am J Med Genet A 2008;146A:2116-2121.

104 Faiyaz-Ul-Haque M, Ahmad W, Zaidi SH, Haque S, Teebi AS, Ahmad M, Cohn DH, Tsui LC: Mutation in the cartilage-derived morphogenetic protein-1 (cdmp1) gene in a kindred affected with fibular hypoplasia and complex brachydactyly (dupan syndrome). Clin Genet 2002;61:454-458.

105 Thomas JT, Kilpatrick MW, Lin K, Erlacher L, Lembessis P, Costa T, Tsipouras P, Luyten FP: Disruption of human limb morphogenesis by a dominant negative mutation in cdmp1. Nat Genet 1997;17:58-64.

106 Faiyaz-Ul-Haque M, Ahmad W, Wahab A, Haque S, Azim AC, Zaidi SH, Teebi AS, Ahmad M, Cohn DH, Siddique T, Tsui LC: Frameshift mutation in the cartilage-derived morphogenetic protein 1 (cdmp1) gene and severe acromesomelic chondrodysplasia resembling grebe-type chondrodysplasia. Am J Med Genet 2002;111:31-37.

107 Faiyaz-Ul-Haque M, Faqeih EA, Al-Zaidan H, Al-Shammary A, Zaidi SH: Grebe-type chondrodysplasia: A novel missense mutation in a conserved cysteine of the growth differentiation factor 5. J Bone Miner Metab 2008;26:648-652.

108 Seemann P, Schwappacher R, Kjaer KW, Krakow D, Lehmann K, Dawson K, Stricker S, Pohl J, Ploger F, Staub E, Nickel J, Sebald W, Knaus P, Mundlos S: Activating and deactivating mutations in the receptor interaction site of gdf5 cause symphalangism or brachydactyly type a2. J Clin Invest 2005;115:2373-2381.

109 Balci S, Demirtas M, Civelek B, Piskin M, Sensoz O, Akarsu AN: Phenotypic variability of triphalangeal thumb-polysyndactyly syndrome linked to chromosome 7q36. Am J Med Genet 1999;87:399-406.

$\checkmark 110$ Holder-Espinasse M, Escande F, Mayrargue E, Dieux-Coeslier A, Fron D, Doual-Bisser A, Boute-Benejean O, Robert Y, Porchet N, Manouvrier-Hanu S: Angel shaped phalangeal dysplasia, hip dysplasia, and positional teeth abnormalities are part of the brachydactyly c spectrum associated with cdmp-1 mutations. J Med Genet 2004;41:e78.

111 Miyamoto Y, Mabuchi A, Shi D, Kubo T, Takatori Y, Saito S, Fujioka M, Sudo A, Uchida A, Yamamoto S, Ozaki K, Takigawa M, Tanaka T, Nakamura Y, Jiang Q, Ikegawa S: A functional polymorphism in the 5 ' utr of gdf5 is associated with susceptibility to osteoarthritis. Nat Genet 2007;39:529-533.

112 Vaes RB, Rivadeneira F, Kerkhof JM, Hofman A, Pols HA, Uitterlinden AG, van Meurs JB: Genetic variation in the gdf5 region is associated with osteoarthritis, height, hip axis length and fracture risk: The rotterdam study. Ann Rheum Dis 2009;68:1754-1760.

113 Valdes AM, Evangelou E, Kerkhof HJ, Tamm A, Doherty SA, Kisand K, Tamm A, Kerna I, Uitterlinden A, Hofman A, Rivadeneira F, Cooper C, Dennison EM, Zhang W, Muir KR, Ioannidis JP, Wheeler M, Maciewicz RA, van Meurs JB, Arden NK, Spector TD, Doherty M: The gdf5 rs143383 polymorphism is associated with osteoarthritis of the knee with genome-wide statistical significance. Ann Rheum Dis 2011;70:873-875.

114 Rouault K, Scotet V, Autret S, Gaucher F, Dubrana F, Tanguy D, El Rassi CY, Fenoll B, Ferec C: Evidence of association between gdf5 polymorphisms and congenital dislocation of the hip in a caucasian population. Osteoarthritis Cartilage 2010;18:1144-1149.

115 Dai J, Shi D, Zhu P, Qin J, Ni H, Xu Y, Yao C, Zhu L, Zhu H, Zhao B, Wei J, Liu B, Ikegawa S, Jiang Q, Ding Y: Association of a single nucleotide polymorphism in growth differentiate factor 5 with congenital dysplasia of the hip: A case-control study. Arthritis Res Ther 2008;10:R126.

116 Southam L, Rodriguez-Lopez J, Wilkins JM, Pombo-Suarez M, Snelling S, Gomez-Reino JJ, Chapman $\mathrm{K}$, Gonzalez A, Loughlin J: An snp in the 5 '-utr of gdf5 is associated with osteoarthritis susceptibility in europeans and with in vivo differences in allelic expression in articular cartilage. Hum Mol Genet 2007; $16: 2226-2232$. 
117 Chapman K, Takahashi A, Meulenbelt I, Watson C, Rodriguez-Lopez J, Egli R, Tsezou A, Malizos KN, Kloppenburg M, Shi D, Southam L, van der Breggen R, Donn R, Qin J, Doherty M, Slagboom PE, Wallis G, Kamatani N, Jiang Q, Gonzalez A, Loughlin J, Ikegawa S: A meta-analysis of european and asian cohorts reveals a global role of a functional snp in the 5 ' utr of gdf5 with osteoarthritis susceptibility. Hum Mol Genet 2008;17:1497-1504.

118 Daans M, Luyten FP, Lories RJ: Gdf5 deficiency in mice is associated with instability-driven joint damage, gait and subchondral bone changes. Ann Rheum Dis 2011;70:208-213.

119 Syddall CM, Reynard LN, Young DA, Loughlin J: The identification of trans-acting factors that regulate the expression of gdf5 via the osteoarthritis susceptibility snp rs143383. PLoS Genet 2013;9:e1003557.

120 Reynard LN, Bui C, Syddall CM, Loughlin J: Cpg methylation regulates allelic expression of gdf5 by modulating binding of sp1 and sp3 repressor proteins to the osteoarthritis susceptibility snp rs143383. Hum Genet 2014;133:1059-1073.

121 Ikegawa S: The genetics of common degenerative skeletal disorders: Osteoarthritis and degenerative disc disease. Annu Rev Genomics Hum Genet 2013;14:245-256.

122 Wang H, Kroeber M, Hanke M, Ries R, Schmid C, Poller W, Richter W: Release of active and depot gdf-5 after adenovirus-mediated overexpression stimulates rabbit and human intervertebral disc cells. J Mol Med (Berl) 2004;82:126-134.

123 Liang H, Ma SY, Feng G, Shen FH, Joshua Li X: Therapeutic effects of adenovirus-mediated growth and differentiation factor-5 in a mice disc degeneration model induced by annulus needle puncture. Spine J 2010;10:32-41.

124 Yan J, Yang S, Sun H, Guo D, Wu B, Ji F, Zhou D: Effects of releasing recombinant human growth and differentiation factor-5 from poly(lactic-co-glycolic acid) microspheres for repair of the rat degenerated intervertebral disc. J Biomater Appl 2013; 29:72-80.

125 Le Maitre CL, Baird P, Freemont AJ, Hoyland JA: An in vitro study investigating the survival and phenotype of mesenchymal stem cells following injection into nucleus pulposus tissue. Arthritis Res Ther 2009;11:R20.

126 Yang X, Li X: Nucleus pulposus tissue engineering: A brief review. Eur Spine J 2009;18:1564-1572.

127 Baumgartner L, Arnhold S, Brixius K, Addicks K, Bloch W: Human mesenchymal stem cells: Influence of oxygen pressure on proliferation and chondrogenic differentiation in fibrin glue in vitro. J Biomed Mater Res A 2010;93:930-940.

128 Markway BD, Tan GK, Brooke G, Hudson JE, Cooper-White JJ, Doran MR: Enhanced chondrogenic differentiation of human bone marrow-derived mesenchymal stem cells in low oxygen environment micropellet cultures. Cell Transplant 2010;19:29-42.

129 Sobajima S, Vadala G, Shimer A, Kim JS, Gilbertson LG, Kang JD: Feasibility of a stem cell therapy for intervertebral disc degeneration. Spine J 2008;8:888-896.

130 Mwale F, Roughley P, Antoniou J: Distinction between the extracellular matrix of the nucleus pulposus and hyaline cartilage: A requisite for tissue engineering of intervertebral disc. Eur Cell Mater 2004;8:58-63; discussion 63-54.

131 Minogue BM, Richardson SM, Zeef LA, Freemont AJ, Hoyland JA: Characterization of the human nucleus pulposus cell phenotype and evaluation of novel marker gene expression to define adult stem cell differentiation. Arthritis Rheum 2010;62:3695-3705.

132 Rutges J, Creemers LB, Dhert W, Milz S, Sakai D, Mochida J, Alini M, Grad S: Variations in gene and protein expression in human nucleus pulposus in comparison with annulus fibrosus and cartilage cells: Potential associations with aging and degeneration. Osteoarthritis Cartilage 2010;18:416-423.

133 Bai X, Xiao Z, Pan Y, Hu J, Pohl J, Wen J, Li L: Cartilage-derived morphogenetic protein-1 promotes the differentiation of mesenchymal stem cells into chondrocytes. Biochem Biophys Res Commun 2004;325:453-460.

134 Feng G, Wan Y, Balian G, Laurencin CT, Li X: Adenovirus-mediated expression of growth and differentiation factor-5 promotes chondrogenesis of adipose stem cells. Growth Factors 2008;26:132-142.

135 Bucher C, Gazdhar A, Benneker LM, Geiser T, Gantenbein-Ritter B: Nonviral gene delivery of growth and differentiation factor 5 to human mesenchymal stem cells injected into a $3 \mathrm{~d}$ bovine intervertebral disc organ culture system. Stem Cells Int 2013;2013:326828.

136 Peroglio M, Eglin D, Benneker LM, Alini M, Grad S: Thermoreversible hyaluronan-based hydrogel supports in vitro and ex vivo disc-like differentiation of human mesenchymal stem cells. Spine J 2013;13:1627-1639. 